\title{
Article \\ Incidence of Large Wood Borers in the Conservation of dehesa Islands Forests in Southwestern Spain
}

\author{
Luis Domínguez ${ }^{1, *(\mathbb{D})}$, Gloria López-Pantoja ${ }^{1}$, David Cremades ${ }^{1}$, Antonia Paramio ${ }^{1}$, Pablo J. Hidalgo ${ }^{2}$ (1) \\ and Israel Sánchez-Osorio ${ }^{1}$ (1) \\ 1 Agroforestry Sciences Department, Escuela Técnica Superior de Ingeniería, Campus El Carmen, \\ University of Huelva, 21007 Huelva, Spain; pantoja@dcaf.uhu.es (G.L.-P.); \\ david.cremades@juntadeandalucia.es (D.C.); antonia.paramio@dcaf.uhu.es (A.P.); \\ isanchez@dcaf.uhu.es (I.S.-O.) \\ 2 Integrative Sciences Department, Faculty of Experimental Sciences, Campus El Carmen, University of Huelva, \\ 231071 Huelva, Spain; hidalgo@uhu.es \\ * Correspondence: luis.dominguez@dcaf.uhu.es; Tel.: +34-959217566
}

Citation: Domínguez, L.; López-Pantoja, G.; Cremades, D.; Paramio, A.; Hidalgo, P.J.; Sánchez-Osorio, I. Incidence of Large Wood Borers in the Conservation of dehesa Islands Forests in Southwestern Spain. Forests 2022, 13, 413. https:// doi.org/10.3390/f13030413

Academic Editor: Daniel J. Johnson

Received: 17 January 2022

Accepted: 2 March 2022

Published: 4 March 2022

Publisher's Note: MDPI stays neutral with regard to jurisdictional claims in published maps and institutional affiliations.

Copyright: (C) 2022 by the authors. Licensee MDPI, Basel, Switzerland. This article is an open access article distributed under the terms and conditions of the Creative Commons Attribution (CC BY) license (https:// creativecommons.org/licenses/by/ $4.0 /)$.

\begin{abstract}
The dehesa is a traditional agrosilvopastoral ecosystem characterized by a savanna-like structure. It has been in decline since the middle of the last century, in particular in agricultural environments where it has been relegated to isolated forests. This paper presents a study into the reduction over the past 50 years. One of the main causes of this decline has been identified as xylophagous insects, specifically the wood borer Cerambyx welensii Kuster (Coleoptera: Cerambycidae). Based on estimations in both the population size, using Jolly Seber models, and the level of tree injury, using a single-index model, the study investigates the role the insect has played in the decline of the dehesa. Surface area loss was found to be greater than $50 \%$, while canopy cover has diminished linearly over the period studied, with the risk of disappearance of the woodland increasing in the same magnitude as borer population density. The highest wood borer population densities observed corresponded to stands with an average canopy cover loss of $1.68 \%$ a year, indicating a risk of completely losing the forest cover in the short term (10-30 years). The proposed tree injury index was successful in categorizing the size of the insect population, and seems to be a useful indicator for describing the relationship between the two variables. According to this indicator, woodlands with more than $10 \%$ of trees with severe or very severe injuries are at risk. Follow-up work should be undertaken to investigate long-term demographic changes in wood borer populations, and management practices should be developed to reduce the population size, minimize forest loss and preserve these relict oak trees in unconnected landscapes.
\end{abstract}

Keywords: Cerambycidae; oak decline; tree mortality; island forests; Quercus dehesa

\section{Introduction}

The dehesas constitute a multifunctional agro-silvopastoral system of savanna-like terrain, whose origins are closely linked in origin to traditional resource uses. Their distribution area, as well as their tree stand density, started to decrease during the second half of the 20th century, with reported overall losses of millions of trees [1-4], diminishing to a series of isolated unconnected areas. According to the literature, three main factors converge to cause the degenerative tendency: (i) land-use changes (including trees cut down for both extensive or intensive agriculture and reforestation with fast-growing species), which have resulted in the disappearance of large patches of dehesa [4-6]; (ii) thinning of trees as a consequence of ever-increasing mechanization and growth in livestock populations [7], coupled with the effects of senescence [8]; and (iii) dieback (oak decline), which has contributed to the gradual disappearance of trees of almost all age classes (see recent review in [9]). With respect to the first of these causes, a regressive period from the 1950s to the 1980s is notable for the extremely high rates of disappearance among trees and entire 
plots. Within the geographical area considered in the present study, reports have accounted for a large number of sick cork oaks (Quercus suber L.) felled during the 1950s in Portugal, followed by a continuous reduction in tree density (reviewed in [4]). On the Spanish side, relatively major dehesa surface area losses beginning in the second half of the twentieth century have been reported [2,3,10], with a period of strong pressure, at the end of the 1970s, to convert oak forests into land for agricultural uses, as a result of which the agricultural matrix grew and many forest plots became isolated. The result was the creation of a highly humanized landscape consisting of forest patches embedded within an agricultural matrix that encompasses some other natural spaces.

Since the 1980s, these trends have slowed, due to increased concerns about conservation, the development of stricter national and regional legislation, and changes regarding the distribution of agricultural development funds within the European Union [8,11]. In particular, the sclerophyllous grazed forests (dehesas) are now recognized as habitats of European interest (Council Directive 92/43/EEC) and are one of the 34 hotspots identified around the world for the enormous diversity of fauna and flora they sustain [12-15]. Based on the EU Biodiversity Action Plan, the Andalusian Regional Government drew up an inventory and protection plan for fragmented forests (namely Island Forests).

The strategic value of these island forests could be essential for maintaining ecosystem services, such as agricultural production [16] important livestock and forestry resources [17-20] as well as acting as reservoirs of biodiversity. This makes them one of the main elements to consider when designing and creating ecological networks connecting the different natural protected areas.

Cork oak plays an important role in the dehesas of southwestern Spain, of which it is considered a representative species, as it provides niches (support for nesting, hollows, etc.) for a diverse range of invertebrate and vertebrate fauna (see references found in [21,22] and consult $[23,24]$ for endangered species). In this respect, the areas under consideration of particular interest for the Iberian lynx (Lynx pardinus Temmink) deemed as an endangered species by the IUCN and considered as an 'umbrella' species [21,25].

Nevertheless, the sustainability of this agricultural system continues to be compromised by an inherent lack of natural regeneration $[17,26,27]$, and oak decline remains a latent problem, such that the status of the dehesas has given rise to a huge concern at both private and administrative levels.

Within the range of abiotic and biotic factors related to episodes of oak decline (see [9] for a recent review and [28] for data for Spain), wood boring insects are considered a contributing or aggravating factor, among the most important being those of the Cerambycidae, Buprestidae, and Curculionidae (particularly Platypodinae) families being of most concern [29]. In terms of the serious damage they cause, the large wood borers are especially notable, in particular Cerambyx cerdo L. [9], and in Southwestern Europe, the sympatric species Cerambyx welensii Kuster [28], as well as Prinobius myardi Mulsant [9,30,31]. Although there are few data on the actual incidence of infestation by these species, some authors have speculated that the predominant factor triggering tree mortality could be, at least in certain areas, the large insect wood borers [28] and specifically C. welensii, as it appears to be the most widespread and abundant [32]. In all instances, they are large species with long larval periods (3-4 years in the case of Cerambyx) and short adult life spans (from May to August. Adults mature inside the tree from the previous September), with males and females both being active at twilight (for more information, see $[33,34]$ ).

The larval activity of these large wood borers is most evident around branches in certain trees and on the trunk in others [34], very probably conditioned by the site of infestation. Infestation may lead to tree death, trees being further weakened by the loss of foliage and biomass, through branches falling and even the trunk breaking (woodland canopy cover being thereby affected), with the indirect effect of the creation of entryways for pathogens [35].

Under the hypothesis that large borers play a determining role in the deterioration and death of dehesas in some areas, this study aimed to assess the risk of disappearance of those 
fragmented forests included in the regional inventory clearly at risk from wood borers and to study the possible role of these insects in this downward trend. For this purpose, we retrospectively evaluate the evolution of their canopy cover in three selected patches with known conservation problems in the search of predictive tendencies, we provide data on the borer population size at the three sites, and we characterize the insect damage to trees using an experimental index proposed as a diagnostic tool. The final goal is to improve management so as to guarantee the survival of these relict areas.

\section{Materials and Methods}

\subsection{Study Area}

Three patches, all included in the regional inventory of fragmented forests, were selected for the study, two in the municipal areas of Almonte and Gibraleón, in the province of Huelva, and the third in Huévar, in the province of Seville, all within the autonomous community of Andalusia (Figure 1). All three patches showed clear signs of been affected by wood borers, such as the presence of recent piles of sawdust and broken or detached branches.

Two of the sites are in the ecotone of a protected natural area of enormous international importance, namely, National and Natural Parks of Doñana, and one (Huévar) is also partially included within the Natura 2000 network.

These sites are essential for the interconnection of species in a hostile agricultural matrix between the Doñana protected area and the Sierra Morena mountain range in the north. During the 1970s and 1980s, a plan to move from rainfed to irrigated crops was implemented in this area of southwestern Spain, with the core activity in Almonte and other localities close to the protected area, affecting forested land [36].

All three sites contain one or more farms that have traditionally sustained livestock and continue to farm livestock of some kind: in Gibraleón, mostly fighting bulls, as well as pigs and horses; in Huévar, cattle and horses; and in Almonte, a small flock of sheep. There is, and has always been, a limited extent of scrubland on the three farms, due to their management history. Further, as a consequence of systematic grazing and harrowing, there is virtually no natural tree regeneration. In Gibraleón and Almonte, the predominant tree species is the cork oak (Q. suber), while in Huévar, this species shares predominance with holm oak (Quercus ilex L. ssp. ballota). Taking the classification proposed by Plieninger et al. [37] for holm oak dehesas ( $n=800$ trees, Figure A1 in Appendix A) as a reference, the selected dehesas would be categorized as middle-aged, estimated to be around 150 years old. The tree density ranges between 25 and 55 trees ha $^{-1}$ and the canopy cover between 9.7\% (Gibraleón) and 21.73\% (Huévar).

The study sites were composed of very different surface areas, ranging from the 240 hectares in Gibraleón to the 1500 ha in Huévar (Figure 1). Wooded areas were analyzed at the levels of plot (wooded area belonging to a patch) and cluster (comprising 200 adjacent trees-207 in the case of Almonte-within a plot). In the case of Huévar, due to its large surface area and the different distribution of tree species, we decided to choose 2 plots and 2 clusters in Huévar (named Huévar1 and Huévar2).

In Gibraleón and Huévar, the study plots covered areas of around 35 ha, with a homogeneous density. In Almonte, by contrast, the density was heterogeneous, which led us to consider three non-contiguous subplots totaling around 35 ha (Figure 1) as one single plot. Insect population size and the severity of damage caused to trees were analyzed at cluster level, while canopy cover loss was analyzed at plot level.

\subsection{Assessment of Loss of dehesa Surface Area}

Each site was diachronically studied in terms of the evolution of the wooded surface area over the period 1957-2010 through comparative analysis of the 9 available orthophotographs (Table A1, Appendix B). In order to do this, each wooded area for each year available was enclosed in a polygon using ArcGis 10.0. The area of each polygon was then calculated to allow comparisons of wooded surface areas between years. 


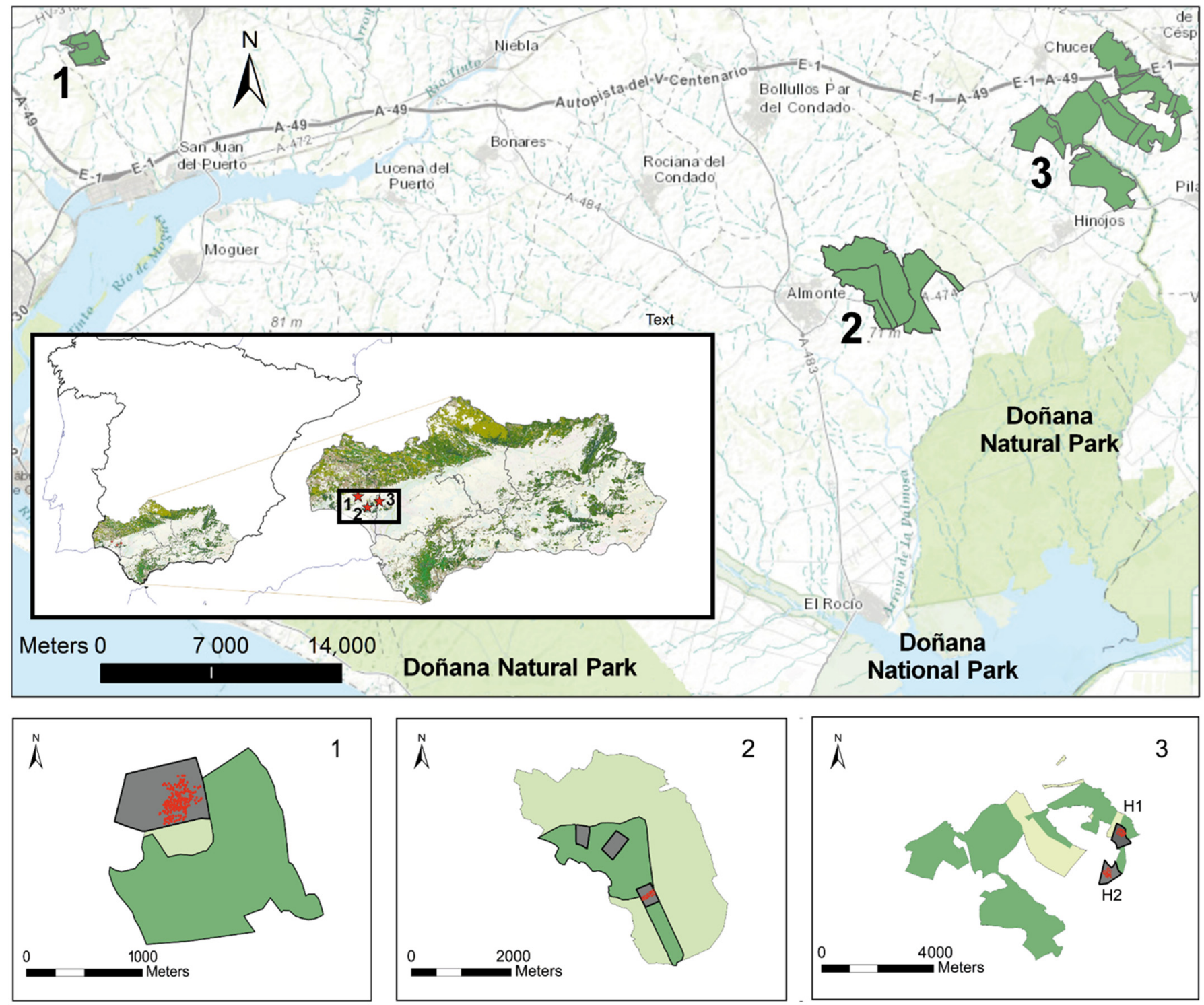

Figure 1. Dehesas considered in the study: 1, Gibraleón; $\left(37^{\circ} 22^{\prime} 10.96^{\prime \prime} \mathrm{N}, 6^{\circ} 53^{\prime} 37.69^{\prime \prime} \mathrm{O}, 34\right.$ m.a.s.1.); 2, Almonte $\left(37^{\circ} 15^{\prime} 43.73^{\prime \prime} \mathrm{N}, 6^{\circ} 28^{\prime} 34.65^{\prime \prime} \mathrm{O}, 80 \mathrm{~m}\right.$ a.s.1.); 3, Huévar. Above, patches of continuous woodland as constituted in 1957. Below, study plot and subplot scheme showing the constitution of the patches in 1977 (light green) and in 2010 (medium green). In dark gray, the study plots (H1 Huévar1 - $37^{\circ} 20^{\prime} 34.55^{\prime \prime}$ N, $6^{\circ} 19^{\prime} 16.58^{\prime \prime}$ O, 67 m.a.s.1.-; H2, Huévar2, -37 $19^{\prime} 40.24^{\prime \prime}$ N, $6^{\circ} 19^{\prime} 34.88^{\prime \prime}$ O, 111 m.a.s.l.-) and subplots (Almonte 3 subplots), within which is the location of the clusters (red dots).

\subsection{Assessment of Canopy Cover Loss}

Changes in canopy cover were analyzed for the period 1977-2010, the starting date being determined by the availability of reliable historical information regarding the phytosanitary condition of the farms (drawing on a combination of personal observations and oral communication with landowners or government technicians). Six orthophotographs from different years were analyzed using ArcGis 10.0 (Table A1, Appendix B). For each of the 6 years, the area of canopy cover was calculated by manually constructing polygons representing the ground covered by the vertical projection of the canopy of individual trees, or entire tree groups, excluding areas in shadow. A review of possible effects of the regional government's protection program was also carried out by similarly contrasting images of the forest patches from 2018 with those from 2013. 


\subsection{Monitoring of the C. welensii Population}

In order to gather basic information on this issue, the adult wood borer population, the insects were monitored following the capture-mark-recapture method. Clusters of 200 trees in each plot (207 in the case of Almonte) were selected and individually labeled (using Cor-plus Ardes tags, Malaga, Spain) to enable the insect population to be estimated and the damage to be characterized. The trees in each cluster were assessed every other day during the adult insect flight period (that is, the period in which adult insects can be detected in the field, between mid-May and the end of August), between 21:15 and 02:00 to coincide with the period of peak daily activity of the insects, following the procedure described by López-Pantoja et al. [33]. Data were collected for the clusters located in Huévar and Gibraleón in 2010, and for Almonte in 2011, yielding data series based on 15 to 38 surveys per year.

All trees were inspected with the help of a flashlight (SA-Q5 7W 300 lumens LED, Cree-Saik, Chile) along the full length of all the thick branches to where they became twigs, on four sides of the trunk, this operation involving two people per cluster per night.

In each session, the insects detected were captured and marked with a numeric and color codes using an indelible marker. Only insects captured for the first time were marked and measured; recaptured ones were noted according to their identifier codes. In both cases, the insects were immediately released back into the same tree from which they had been captured.

The capture-mark-recapture data set was analyzed using Jolly-Seber models [38-41] executed in POPAN 5.0 [41] implemented with Program MARK 7.0 [42] to calculate the insect superpopulation of the four plots. To calculate the values of the parameters recapture $(p)$ survival $(\phi)$, superpopulation $(\mathrm{N})$ and recruitment $(\beta)$, models were designed which used the Logit ( $p$ and $\phi)$, the Log and the multinomial MLogit functions as link functions, respectively. All possible combinations were tested considering the variation over time $(\mathrm{t})$, the variation according to sex $(\mathrm{g})$ and the interaction of both $(\mathrm{t} \times \mathrm{g})$ in each of the parameters.

The saturated model was fitted to the data with Program RELEASE [43] using the version provided with MARK, together with Program U-CARE [44], and these programs were used to calculate the inflation variance (c-hat), obtaining information about possible deviations in the fit to the data. The best-fitting models were selected according to the corrected Akaike's Information Criterion (AICc), when necessary, using the inflation variance to obtain the quasi-likelihood AIC (QAICc) as a goodness-of-fit indicator.

\subsection{Characterization of Wood Borer Damage}

This part of the work was carried out in 2010 in the case of the plots located in Huévar and Gibraleón and in 2011 in Almonte. The trees selected in each plot were classified in terms of insect damage as evidenced by adult exit holes.

Individual scores were assigned to each tree, using a similar system to that described by other authors [35,45-47]. In our case, the total number of exit holes in the trunk and branches were divided into the following five injury categories (ICs): 0 (zero injuries) for no holes; 1 (potential injury) for 1 to 50 holes; 2 (marked injury) for more than 50 holes; 3 (severe injury) for more than 50 holes, partially or totally merged and forming significant wounds; and finally, 4 (highly severe injury), for large wounds, with hollowing of the trunk and/or branches.

\section{Results}

\subsection{Loss of dehesa}

The average tree loss from 1957 up to the year 2010 was greatest in Almonte, with very high overall figures (81\%; 1116 ha of the original $1380 \mathrm{ha}$ ) compared to relatively low values in Gibraleón (18\%; 40 ha of the original 214 ha) and moderate losses in Huévar (38\%; 780 ha of the original 2173 ha) (Figure 2). 


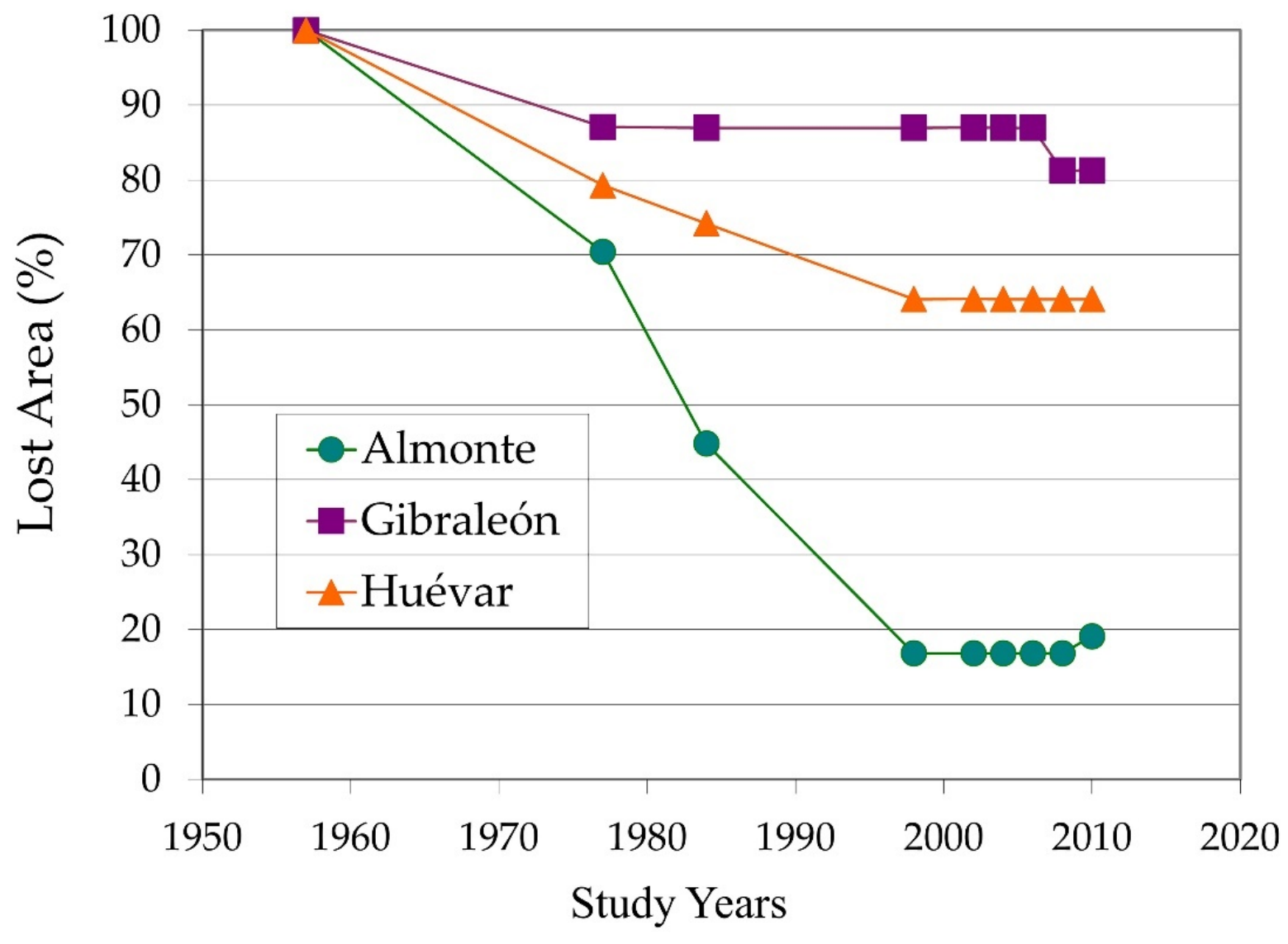

Figure 2. Lost dehesa surface percentage of each study patch throughout of the analyzed period (1957-2010).

The rate of decline was not constant, and displayed greater intensity in some periods compared to others. During the first 30 years (period 1957-1984), all three study areas experienced the loss of significant swaths of dehesa. In the Gibraleón site, the decline was more or less halted around 1977, while it remained particularly intense in Almonte until 1998. In the location of Huévar, tree loss likewise continued until the same time, although somewhat less severely in comparison with Almonte (Figure 2). This general pattern continued such that, at the turn of the present century, the decline was significantly slowed in all locations, to the point that a certain degree of recovery could be noted due to the appearance of regenerated woodland.

Taking as reference the before mentioned regressive stage of the dehesa (1957-1984) mentioned above, the decline over the whole area of study amounted to $32 \%$, though particularly high in Almonte (56\%). The percentage loss also remained relatively high (19\%) in the later stage (1984-2010).

The verbal information complementing the orthophotographic analysis established that the main causes of the loss were firstly, the uprooting of trees in entire farms as a result of the shift from forestry to agriculture (mainly in Almonte), and secondly, the construction of transport infrastructures (Almonte-Hinojos road and the Seville-Huelva highway). The result of the process, in any case, has been the fragmentation of the woodland area, which was once continuous, together with the isolation of forest patches (see Figure 1).

In terms of current mean tree densities that currently exist in the areas studied, the tree losses that have occurred through the disappearance of whole woodland patches over the 
53 years covered by this study's review, amount to about 1000 trees in Gibraleón, 19,500 in Huévar and 58,000 in Almonte. The figures are high, particularly considering that they are underestimated by virtue of the reference density that has been taken into consideration.

\subsection{Canopy Cover Loss}

The tree coverage analysis, using Geographical Information System data for the study period (1977-2010), revealed that in percentage points the largest reduction in canopy cover occurred in Gibraleón, with 57\% of canopy cover loss (Figure 3), followed by Almonte (43\%), and somewhat lower although still with a high value, Huévar2 $(37 \%)$, while there was considerably less loss in Huévar1 $(16 \%)$. The canopy cover decrease was linear $\left(R^{2}>0.91\right.$ in all cases), and hence, it was possible to forecast at what point the plots would lose all of their canopy cover, on the assumption that the rate of loss remains constant, and there is no renewal from natural regeneration or reforestation (Figure 3).

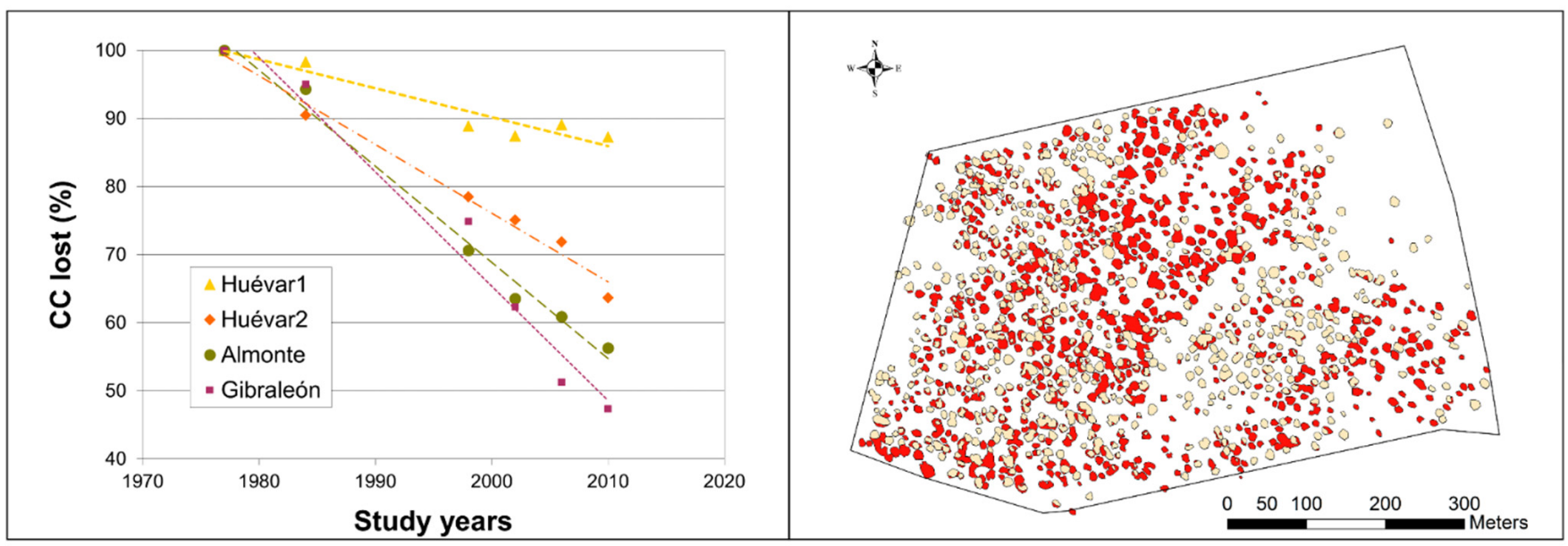

\begin{tabular}{|l|l|c|c|c|}
\hline \multirow{2}{*}{ Plot } & & & \multicolumn{2}{c|}{$\begin{array}{c}\text { Year of predicted } \\
\text { zero CC }\end{array}$} \\
\cline { 4 - 5 } \multicolumn{1}{|c|}{} & EQ & $\mathrm{R}^{2}$ & Low. & Upp. \\
\hline Gibraleón & $\mathrm{y}=-1.679 \mathrm{x}+3423.4$ & 0.9678 & 2026 & 2048 \\
\hline Almonte & $\mathrm{y}=-1.411 \mathrm{x}+2891.4$ & 0.9882 & 2040 & 2056 \\
\hline Huévar2 & $\mathrm{y}=-1.009 \mathrm{x}+2093.6$ & 0.9846 & 2060 & 2087 \\
\hline Huévar1 & $\mathrm{y}=-0.424 \mathrm{x}+938.3$ & 0.9157 & 2110 & 2278 \\
\hline
\end{tabular}

Figure 3. Canopy cover decline. Top left: canopy cover loss by percentage in the four study plots since 1977. Top right: Canopy cover loss in Gibraleón; red polygons represent remaining canopy in 2010; clear polygons represent remaining canopy in 2010. Bottom: Equations predicting year of total canopy cover; $\mathrm{R}^{2}$; lower (Low) and upper limits (Upp) of zero value at the current rate of loss.

Taking into account the updated data from 2018, the loss of canopy cover slows down and even reverses (in all sites except Gibraleón) from 2010, although the decrease in the number of polygons continues in all plots. According to the model that best fits the entire data set (Year $=\mathrm{CC}+$ number of polygons), the degradation of plots detected up to 2010 remains linear until 2018 (adjusted $R^{2}>0.95, p<0.001$ in all cases). If we extrapolate the trend observed for the plot to the entire site, the whole Gibraleón stand would be lost within a maximum period of just over 20 years, while Almonte would be lost within the next 30 to 100 years. With respect to the Huévar site, this could disappear within the next 50-80 years, if the overall evolution follows the pattern detected in the Huévar plot2; alternatively, it could have a much longer period of decline (140-270 years) should it follow the pattern in Huévar1 (Figure 4). 


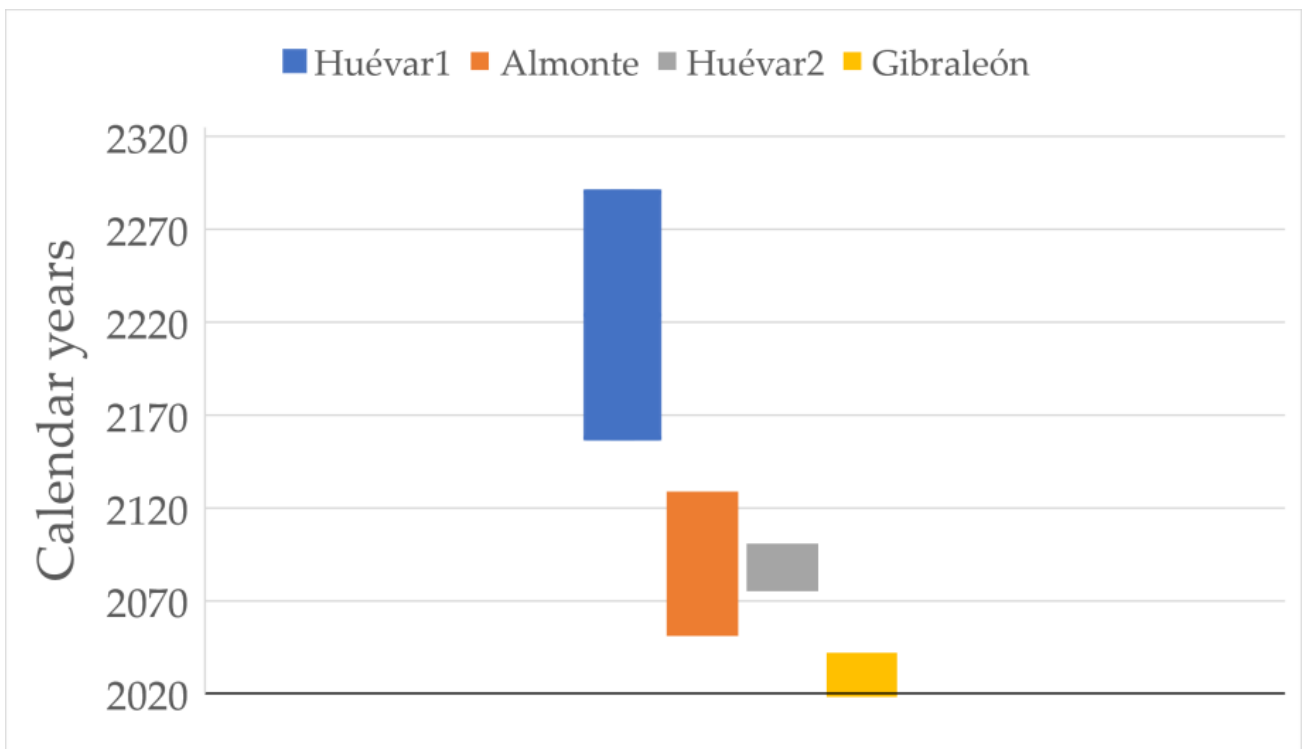

Figure 4. Predicted lifespan of the four plots studied according to the rate of cover loss rate. The end points of the bars indicate upper and lower limits at 95\% confidence level.

\subsection{Cerambyx welensii Population Size}

The estimated superpopulation sizes according to the best models for each cluster were: Gibraleón, 3809.19 insects according to the model $\phi \mathrm{g} \times \mathrm{tpg} \times \mathrm{t} \beta \mathrm{t}$; Huévar2, 2627.71 insects according to the model $\phi \operatorname{tpg} \times \mathrm{t} \beta \mathrm{g} \times \mathrm{t}$ and Huévar1, 432.54 insects according to the model $\phi \operatorname{tpt} \beta \mathrm{g} \times \mathrm{t}$; in the case of Almonte 1987.39 insects according to the model $\phi g p g \beta \mathrm{t}$.

\subsection{Characterization of the Damage Caused by Large Wood Borers}

The sampled provided evidence that somewhat more than $20 \%$ of the trees showed severe to highly severe injuries, with considerable trunk and branch damage, together with an associated risk of biomass loss or even tree death (Figure 5). Overall, around $40 \%$ of the trees were rated as healthy.

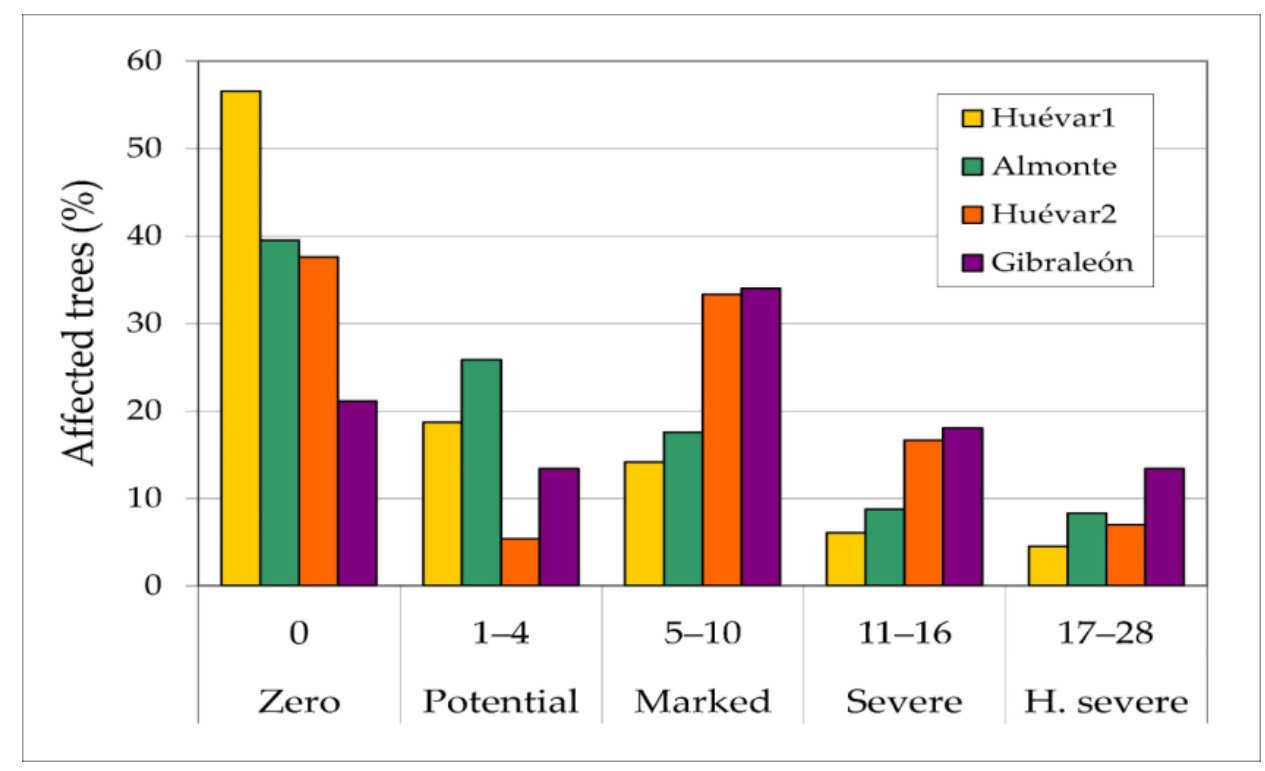

Figure 5. Percentages of trees affected by wood borer insects in each study plot, according to damage categories. 
In the least damaged cluster (Huévar1), more than half of the trees (58\%) showed no visible injuries, and just $12.5 \%$ of trees showed simultaneous trunk and branch injuries. In contrast, in the cluster with the worst status (Gibraleón), nearly 80\% of trees had visible injuries and the observed extent of injury was greater than in the other the clusters in almost all categories, with $44 \%$ of the trees showing trunk and branch injuries. In the intermediate clusters, around two-thirds of the trees had visible injuries $(61 \%$ in Almonte; $64 \%$ in Huévar2), with a quarter of the trees showing both trunk and branch injuries. Though overall scores in these two sites were similar, a slightly higher percentage of trees had severe injuries in Almonte than in Huévar 2.

The injury index yielded a gradient coincident with the insect population size (Figure 6).

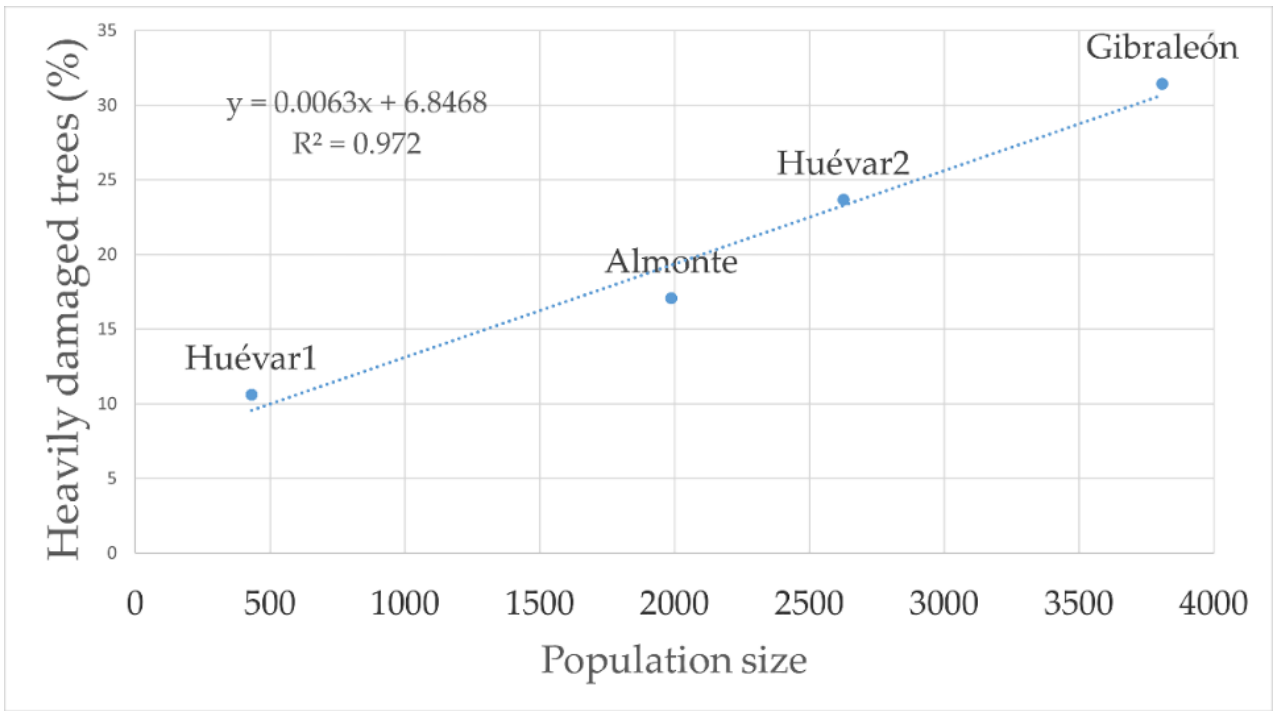

Figure 6. Linear relationship between wood borer population size and degree of severe damage to trees.

Specifically, the largest wood borer superpopulation observed corresponded to stands in which $31.4 \%$ of the trees showed severe or highly severe wood borer damage, with an average canopy cover loss of $1.68 \%$ a year, indicating a short-term risk of completely losing the forest cover (10-30 years). Further, an intermediate population size was found in stands where $17.01-23.6 \%$ of the all the trees studied manifested severe or very severe symptoms of infestation, with an annual average canopy cover loss of $1.13 \%$, implying a risk of disappearance of the entire forest cover in the relative short term (45-90 years). Lastly, the lowest population size detected corresponded to forest stands with $10.6 \%$ of the trees showing severe or highly severe injuries, with a yearly average canopy cover loss of $0.42 \%$, suggesting a long term risk of the entire forest cover disappearing in the long term (100-260 years).

\section{Discussion}

The rate of dehesa decline which took place during the period of intensive reduction (1957-1984) positioned the area of study slightly above the highest figures from other regions of the autonomous community of Andalusia, such as the Sierra Morena (24\%, [3]) or the Sierra Norte (20-25\%, [2]). The overall loss has also continued up to the present day, although with a deceleration to that occurring in other geographical scenarios ([48], citing Miguel et al. [49]). In general, this loss of dehesa corresponded to a change in activity from forestry to various agricultural dryland crops, thus limiting the role of isolated Quercus trees to that ecological connectors between the surrounding protected sites. Broadly speaking, the terrains sustaining the dehesas were not thereafter engaged in intensive agriculture, rather their transformation was the result of changes to introduce cultivation in polytunnels, which occurred in the zone in the 1970s and affected large forest areas (mainly pine forests 
of Pinus pinea L.). Such deforestation still takes place today due to the substantial economic benefits that this intensive farming system provides the region. Despite efforts to preserve the forestry ecosystems [36,50], the effects on the region highlight the transformative power in the pursuit of economic gain.

What is especially surprising, however, in view of the current perspective, is that in the study sites located closest to the protected natural areas (in particular that of Almonte), significant loss of dehesa surface area was recorded far beyond the declaration dates of the natural spaces (1969 for the National Park of Doñana and 1989 for the Natural Park of Doñana), despite the enormous environmental significance that of these ecosystems, at both the general Mediterranean level [23] and the specific local level for the areas studied. The territorial planning decisions that led to the transformation of these lands could have been incorporated, at least in the case of the cork oak dehesas, the phytosanitary arguments set out below. According to oral testimonies obtained from forest management technicians and field operators, a series of inventories were implemented in the 1970s to determine the extent of damage caused by the large wood borer insects, with the aim of authorizing the transformation of farms or even the complete elimination of trees. No records or official documentation on the matter are extant, but the existence of the alleged high levels of infestation is supported by anecdotal evidence (print media and personal observation) of certain confrontations at the time between conservationist associations and the administration regarding the poor state of conservation of the dehesas located in the Doñana area. Given this evidence, it is reasonable to conclude that the state of the diseased trees caused by the large wood borers was already evident 30-40 years ago.

The persistence into the present time of serious phytosanitary problems corroborates the low efficiency attained by the removal of entire woodland patches as a sole remedy to prevent the large wood borer insect infestations. In fact, it is likely that the creation of the isolated forest patches as a result of large-scale surface removal may have condemned these areas to even more rapid deterioration $[35,51,52]$ and the Gibraleón plot could be a case in point.

The removal of affected and dead trees does, however, appear to have yielded noticeable results concerning cases of intense outbreaks of the biennially generated cerambycid E. rufulus, achieving short-term reductions in insect population densities (Riggins et al. [53], citing Donley [54]). However, in the absence at present of similar official actions supervised by the administration, the quantitative importance of the existing damage to trees is transposed into the owners' desire to forestall economic losses of forest products (chiefly cork and acorns mainly) and to improve the aesthetics of their farms. This leads them to carry out, on an individual level, silvicultural practices such as the pruning and removal or burning of branches and fallen or very perforated trunks, along with the removal of still living, but unprofitable trees, as reflected in part of the loss of canopy cover found in this study.

As evidenced in the present study, there is a clear agreement in the gradient shown by three different factors: the population size of borer insects, the injury caused to the trees by such insects and the canopy cover loss over time. The tree injury index used in this study, with the addition of extended scores (main branches, lesions and cavities), would seem to have a good predictive capacity for the wood borer population size classes to which the injury is attributed. For this reason, the index could be applied to the diagnosis of other dehesas in the Mediterranean basin, for preventive, monitoring or management purposes. This is the case of montados in Portugal or pascolo arborato in Italy.

The effects of wood borers instigate a gradual loss of canopy cover as well as complete tree death resulting from breakage of branches and trunks with highly severe damage and/or removal of damaged trees by landowners. It would be logical to deduce that, in the absence of other causes, the larger the population size, the poorer the state of the forest and the higher the risk of its disappearance. A high percentage of the trees in the Almonte monitoring plot are infested by $C$. florentinus and B. mediterranea (unpublished data) and a smaller percentage by other pathogens, but these infestations does not seem to result 
in tree mortality. This apparently low impact on tree health of damage by other biotic agents has also been observed in the other plots in the study area. Similarly, evidence of $P$. cinnamomi in the area has been noted, but the symptoms observed do not suggest that it causes widespread tree losses. Hence, considering the apparent lesser effect of these other pests and pathogens in the area, it seems evident that, at least in recent decades, the agent responsible for tree mortality is $C$. welensii. It cannot be proven that this species is responsible for earlier tree deaths (up to 50 years ago), although our knowledge of the area (since the 1980s) and the information collected from interviews with farm owners, field workers and technicians (concerning the previous decade) suggest that dehesa decline over this period is closely related to the presence of $C$. welensii. The weakening of host trees, due to the other factors may be sufficient to allow borers to gain easy access to them. Consequently, we could speculate that the equilibrium maintained between hosts and pathogens broke down a few decades ago as a result of some external factor, such us the entry of new pathogens, changing climatic conditions, and possibly management practices. From that moment, the populations of borers grew to a point from which to date there has been no return.

It would be of great interest to analyze the records of the different farms in detail, to assess the effect management strategies may have had on the changes in insect populations on their land. In this respect, it is striking that the conditions of the two Huévar plots are so different, given their geographical proximity; in fact, they pertain to the same patch and even of the same farm with apparently similar forestry management practices. Besides unknown factors associated with the past management of the estate, a clear difference between the two plots is the percentage of holm oak trees $(51 \%$ in Huévar1 vs. 9\% in Huévar2), the plot with the higher percentage, Huévar1, recording a smaller wood borer population and also a lower woodland injury score. In American Quercus stands, a high degree of tree species diversity has been cited as a factor contributing to reducing wood borer effects [53], yet this has not been proven in the case of the Iberian oak tree species. Although $C$. welensii and $C$. cerdo both use both $Q$. suber and $Q$. ilex as hosts, it has been suggested that $C$. welensii may have a preference for the former, whilst $C$. cerdo (with testimonial presence in the area, unpublished data) for the latter. A further possible factor differentiating the two hosts is that the more extensive management tasks undertaken for cork oak may predispose these trees to rapid wood borer colonization (most notably, poorly executed cork harvesting), the trees being visited by females to lay eggs in the newly generated access routes (personal observation).

Based on the size and conservation status of the island forests studied, it is probable that Gibraleón will disappear completely in the short term, as predicted by the canopy cover evolution models. In the case of Almonte, the patch may lose tree density and become fragmented before disappearing completely in the medium term, whilst Huévar, being larger and presenting greater heterogeneity, may end up becoming fragmented, some of which may persist long-term. In conclusion, one of the last possibilities for the interconnection of natural native forests is gradually disappearing. Further actions are needed to maintain these centers of biodiversity as they are the key factor for the development of ecological corridors.

\section{Management Suggestions}

The elimination of individual trees that are very severely affected, although alive, as done by the owners of some farms, might actually have little effect on the health of the forest overall. Nevertheless, this hypothesis should be checked by continuing the sampling carried out so far.

According to the injury index, woodlands with more than $10 \%$ of seriously affected trees (showing severe or highly severe injuries) should be monitored. At the other end of the spectrum, populations of fewer than 200 insects/cluster do not pose an immediate risk to the woodland, but as the trees already show clear symptoms of infestation, this would suggest that we should be alert to the threat from these magnitudes. 
In the case of woodlands that are already in a poor condition, forecasts regarding the persistence of the wooded stands are worrying, especially in light of the combination of aggravating factors. Firstly, we should recall the nature of those stands in which more than $90 \%$ ( $80 \%$ in Almonte) of the trees have diameters of more than $30-50 \mathrm{~cm}$, suggesting ages of 60-100 years or more (based on estimates for Q. ilex by Plieninger et al. [37]). Age is related to a greater accumulation of stress, predisposing trees to wood borer colonization [53]. Considering the estimated longevity of $Q$. suber to be around 250-300 years [45], most of the specimens are reaching the end of the first third of their life, and the woodland is nearly halfway through its productive cycle (around the age of 200 years). Secondly, the almost complete lack of natural regeneration constrains renewal and maintains the top-heavy population pyramid. This inversion, which seems inherent to the current management practices in dehesas $[27,46]$, together with the lack of natural seed dispersing agents (the jay, Garrullus glandarius L. not nesting in the study areas), tends to result in inertia, although the situation could in part be alleviated by the transplanting of young trees.

With this in mind, although this part of the southwestern Iberian Peninsula appears to be a potentially suitable area for the recovery of the cork oak [47] through reforestation initiatives, such as those carried out in recent years by some private landowners in the study area, most of the predictive scenarios taking account of climate change have forecasted maintenance problems for the cork trees (for more specific estimates, see [28,48]). Other factors linked to climate change and related to the behavior of pest and pathogen species [15,49,50], even including even the likelihood of increased fire risk [51] paint a far more pessimistic picture, suggesting that it will be necessary to tackle the problem through different approaches.

\section{Conclusions}

This study provides new data suggesting that large wood borers such as C. welensii are a key factor in the decline in health status of Spanish dehesas throughout the study area, and moreover, could have played a damaging role for decades. The scale of the problem is vast and to address the control of relatively large areas requires coordination, effort, persistence, and investments which are likely not feasible for private landowners.

The situation detected in the woodland studied indicates that it is important to continue tracking insect populations to shed light on their long-term evolution with respect to climate change, and also to determine the effect that management practices adopted by some landowners (essentially, the clearing of dead and very damaged trees) could have on these populations. In this regard, it is interesting to continue to search for better tools to monitor insect populations and provide a diagnosis of woodland status. Ideally, these should be easy to access and implement, so that tasks do not necessarily need to be carried out by specialists.

Further, the risk of woodland disappearance, together with the apparent threat exerted by the large wood borers, indicate that campaigns should be undertaken to reduce their population sizes. Some measures in this regard are currently being undertaken in some parts of Spain, and these have experimentally confirmed the effectiveness of baited traps [52,53].

Considering the severity and scale of the problem, enhanced coordination and effectiveness could be achieved if regional governments were to become involved, supervising and possibly also funding the necessary operations, preferably within an integrated pest management strategy. Within such a strategy, the local authorities should come to an arrangement with the farm owners regarding the removal of tree remains and ancient specimens, in order to preserve the valuable niches provided by forests and particularly dehesas adjacent to protected areas. Alongside these strategies, management practices should be encouraged which promote natural woodland regeneration (for instance, by recovering the ancient rotation systems) or at least the incorporation of young specimens through reforestation to guarantee the survival of this sustainable exploitation system. 
Author Contributions: Field work, A.P., D.C., I.S.-O., G.L.-P. and L.D.; data analysis, L.D.; writing—original draft preparation L.D.; writing—review and editing, L.D., I.S.-O., A.P., G.L.-P. and P.J.H.; funding administration, I.S.-O. All authors have read and agreed to the published version of the manuscript.

Funding: The field work was undertaken within projects funded by the Council for the Environment of the Regional Government of Andalusia.

Data Availability Statement: The data presented in this study are openly available in Open Science Framework repository at https:/ / DOI10.17605/OSF.IO/Q7DC6 (accessed on 16 January 2022), reference number Q7DC6.

Acknowledgments: We received strong support from Rubén Fernández Villarán and Cristina Pérez-Carral for the management and decisions about the GIS. We are also grateful to E. Paramio, L. Borruecos, J. M. Caraballo, J. A. Domínguez-Feria, D. Barja, F. J. García, C. Malia, A. Rincón, M. Salado, M. A. Gay and especially R. Tapias and P. Alesso for their help with the monitoring carried out. Further, we would like to thank all of the landowners for the permission granted to work on their estates.

Conflicts of Interest: The authors declare no conflict of interest.

\section{Appendix A}
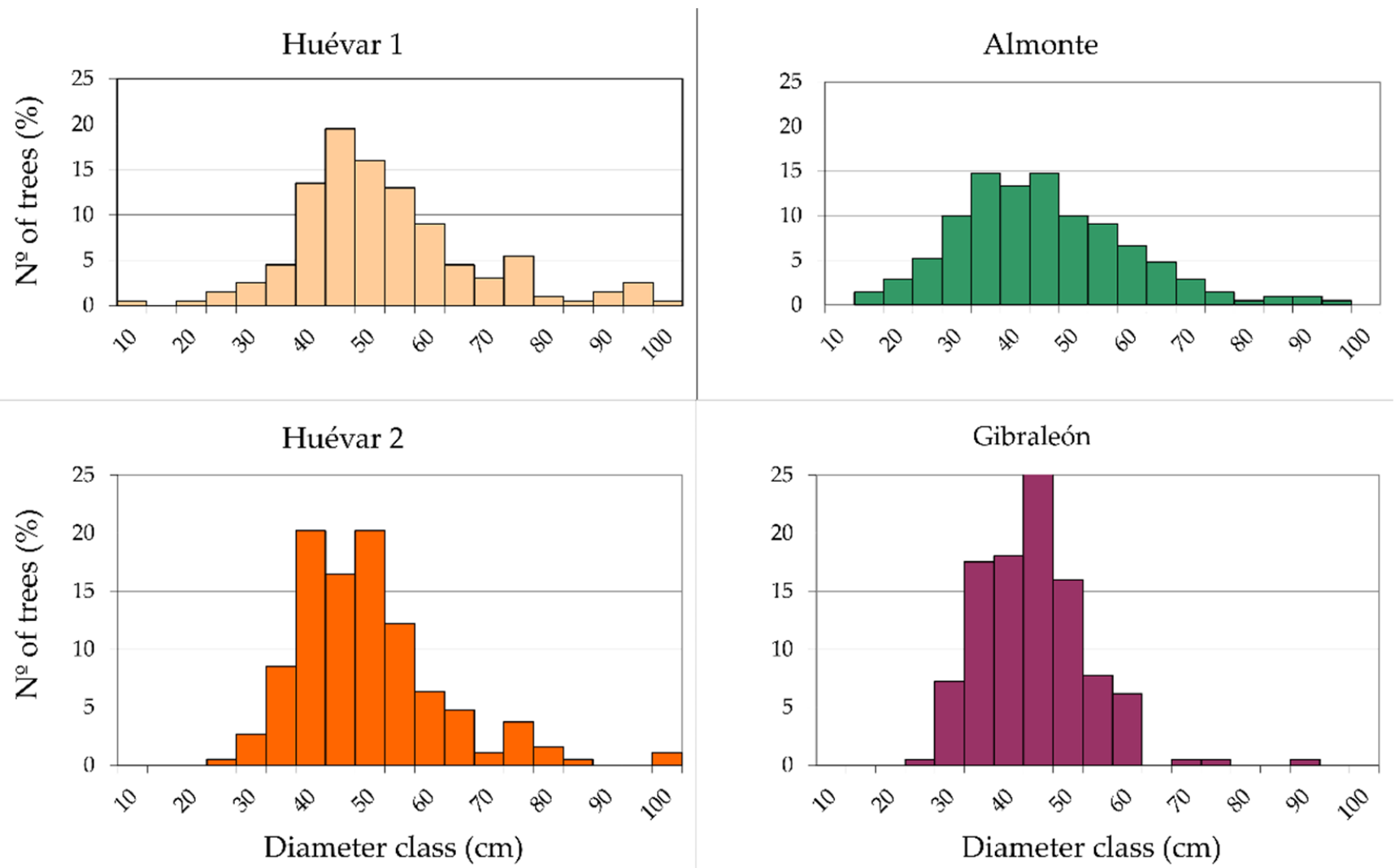

Figure A1. Frequency distributions of the $5 \mathrm{~cm}$ size classes for each cluster in the study area. Tree samples (Q. ilex individuals/Q. suber individuals): Huévar1, 101/99; Almonte, 1/206; Huévar2, 19/189; Gibraleón, 0/200). 


\section{Appendix B}

Table A1. Characteristics of the orthophotos used in each section of the diachronic study (WA, wooded area; CC, canopy cover) according to the information obtained from the regional government: http:/ / www.juntadeandalucia.es/medioambiente/site/rediam/menuitem.aedc2250f6db8 3cf8ca78ca731525ea0/?vgnextoid=0863d61d8470f210VgnVCM2000000624e50aRCRD\&lr=lang_es (accessed on 19 July 2020). Orthophotos available from 2004 onwards correspond to odd-numbered years for Gibraleón and to even-numbered years for all the other areas. BW: black and white; C: color; NP: unspecified.

\begin{tabular}{ccccccc}
\hline \multirow{2}{*}{ Flight Year } & Flight Scale & Ortophoto Scale & Resolution & Mode & \multicolumn{2}{c}{ Study Sections } \\
\cline { 5 - 8 } & & & & WA & CC \\
\hline 1956-1957 & $1: 33,000$ & $1: 10,000$ & $1 \mathrm{~m}$ & BW & $\mathrm{x}$ & \\
\hline $1977-1980$ & $1: 18,000$ & $1: 5000$ & $0.5 \mathrm{~m}$ & BW & $\mathrm{x}$ & $\mathrm{x}$ \\
\hline 1984 & $1: 30,000$ & $1: 10,000$ & $1 \mathrm{~m}$ & BW & $\mathrm{x}$ & $\mathrm{x}$ \\
\hline 1998 & $1: 60,000$ & $1: 10,000$ & $1 \mathrm{~m}$ & $\mathrm{C}$ & $\mathrm{x}$ & $\mathrm{x}$ \\
\hline $2001-2002$ & $1: 20,000$ & $1: 10,000$ & $0.5 \mathrm{~m}$ & BW & $\mathrm{x}$ & $\mathrm{x}$ \\
\hline $2004-2005$ & $1: 60,000$ & $1: 10,000$ & $0.5 \mathrm{~m}$ & $\mathrm{C}$ & $\mathrm{x}$ & \\
\hline $2006-2007$ & $\mathrm{NP}$ & $1: 10,000$ & $0.5 \mathrm{~m}$ & $\mathrm{C}$ & $\mathrm{x}$ & $\mathrm{x}$ \\
\hline $2008-2009$ & $\mathrm{NP}$ & $1: 10,000$ & $0.5 \mathrm{~m}$ & $\mathrm{C}$ & $\mathrm{x}$ & \\
\hline $2010-2011$ & $\mathrm{NP}$ & $1: 10,000$ & $0.5 \mathrm{~m}$ & $\mathrm{C}$ & $\mathrm{x}$ & $\mathrm{x}$ \\
\hline
\end{tabular}

\section{References}

1. Elena-Roselló, M.; López-Márquez, J.A.; Casas-Martín, M.; Sánchez del Corral, A. El Carbón de Encina y la Dehesa; INIA. MAPA: Madrid, Spain, 1987.

2. Joffre, R.; Rambal, S.; Ratte, J.P. The dehesa system of southern Spain and Portugal as a natural ecosystem mimic. Agrofor. Syst. 1988, 45, 57-79. [CrossRef]

3. Fernández-Alés, R.; Martín, A.; Ortega, F.; Ales, E.E. Recent changes in landscape structure and function in a Mediterranean region of SW Spain (1957-1984). Landsc. Ecol. 1992, 7, 3-18. [CrossRef]

4. Sampaio, C.; Camilo-Alves, P.; Esteves da Clara, M.I.; Cabral de Almeida, N. Decline of Mediterranean oak trees and its association with Phytophthora cinnamomi: A review. Eur. J. For. Res. 2013, 132, 411-432.

5. Schroeder, C. Dinámica de las Dehesas de Sierra Morena; Dirección General de la Red de Espacios Naturales Protegidos y Servicios Ambientales. Consejería de Medio Ambiente. Junta de Andalucía: Andalusia, Spain, 2005. Available online: http://www.juntadeandalucia.es/medioambiente/consolidado/publicacionesdigitales/CA-230-34_DINAMICA_DE_LAS_ DEHESAS_DE_SIERRA_MORENA/CA-230-34.htm (accessed on 28 November 2016).

6. Torres, E. Evolución histórica de las dehesas y su gestión. In Manual Para la Gestión Sostenible de las Dehesas Andaluzas. Foro Para la Defensa y Conservación de la Dehesa; Alejano, R., Domingo-Santos, J., Fernández-Martínez, M., Eds.; "Encinal”; Universidad de Huelva: Huelva, Spain, 2011. Available online: http:/ /hdl.handle.net/10272/6641 (accessed on 28 November 2016).

7. Pulido, F.J.; Díaz, M.; Hidalgo, S.J. Size-structure and regeneration of holm oak (Quercus ilex) forests and dehesas: Effects of agroforestry use on their long-term sustainability. For. Ecol. Manag. 2001, 146, 1-13. [CrossRef]

8. Moreno, G.; Pulido, F.J. The functioning, management and persistence of dehesas. In Agroforestry in Europe: Current Status and Future Prospect; Rigueiro, A., McAdam, J., Mosquera-Losada, M.R., Eds.; Springer: Dordrecht, The Netherlands, 2009 ; pp. 127-160.

9. Sallé, A.; Nageleisen, L.M.; Lieutier, F. Bark and wood boring insects involved in oak declines in Europe: Current knowledge and future prospects in a context of climate change. For. Ecol. Manag. 2014, 328, 79-93. [CrossRef]

10. Calvo-Iglesias, M.S.; Fra-Paleo, U.; Crecente-Maseda, R.; Díaz-Varela, R.A. Directions of change in land cover and landscape patterns from 1957 to 2000 in agricultural landscapes in NW Spain. Environ. Manag. 2006, 38, 921-933. [CrossRef]

11. Cowling, R.M.; Rundel, P.W.; Lamont, B.B.; Arroyo, M.K.; Arianoutsou, M. Plant diversity in mediterranean-climate regions. Trends Ecol. Evol. 1996, 11, 362-366. [CrossRef]

12. Médail, F.; Quézel, P. Hot-Spots analysis for conservation of plant biodiversity in the Mediterranean Basin. Ann. Mo. Bot. Gard. 1997, 84, 112-127. [CrossRef]

13. Cuttelod, A.; García, N.; Abdul Malak, D.; Temple, H.; Katariya, V. The Mediterranean: A biodiversity hotspot under threat. In The 2008 Review of The IUCN Red List of Threatened Species; Vié, J.-C., Hilton-Taylor, C., Stuart, S.N., Eds.; IUCN: Gland, Switzerland, 2008; pp. 1-13.

14. FAO. Climate Change Guidelines for Forest Managers; FAO Forestry Paper No. 172; FAO: Rome, Italy, 2013. 
15. Campos, P.; Ovando, P.; Montero, G. Does private income support sustainable agroforestry in Spanish dehesa? Land Use Policy 2008, 25, 510-522. [CrossRef]

16. Fernández, N.; Palomares, F. The selection of breeding dens by the endangered Iberian lynx (Lynx pardinus): Implications for its conservation. Biol. Conserv. 2000, 94, 51-61. [CrossRef]

17. Ramírez-Hernández, A.; Micó, E.; Marcos-García, M.A.; Brustel, H.; Galante, E. The "dehesa", a key ecosystem in maintaining the diversity of Mediterranean saproxylic insects (Coleoptera and Diptera: Syrphidae). Biodivers. Conserv. 2014, 23, 2069-2086. [CrossRef]

18. Díaz, M.; Campos, P.; Pulido, F.J. Spanish Dehesas: A Diversity in land-use and wildlife. In Farming and Birds in Europe; Pain, D.J., Pienkowski, M.W., Eds.; Academic: London, UK, 1997; pp. 178-209.

19. Pulido, F.J.; Marañón, T. Diversidad ecológica y sostenibilidad ecológica y económica de los sistemas adehesados. Ecosistemas 2003, 12, 1-10. Available online: http:/ / www.revistaecosistemas.net/index.php/ecosistemas/article/view/229 (accessed on 28 November 2016).

20. Palomares, F.; Revilla, E.; Calzada, J.; Fernández, N.; Delibes, M. Reproduction and pre-dispersal survival of Iberian lynx in a subpopulation of the Doñana National Park. Biol. Conserv. 2005, 122, 53-59. [CrossRef]

21. Olea, L.; San Miguel-Ayanz, A. The Spanish dehesa. A Mediterranean silvopastoral system linking production and nature conservation. Grassl. Sci. Eur. 2006, 11, 3-13.

22. Carrasco, A. Procesos de Decaimiento Forestal (la Seca), Situación del Conocimiento; Consejería de Medio Ambiente, Junta de Andalucía: Andalusia, Spain, 2009.

23. Rassati, D.; Lieutier, F.; Faccoli, M. Alien Wood-Boring Beetles in Mediterranean Regions. In Insects and Diseases of Mediterranean Forest Systems; Paine, T.D., Lieutiers, F., Eds.; Springer International Publishing: Berlin/Heidelberg, Germany, 2016; pp. 293-327.

24. López-Pantoja, G.; Dominguez, L.; Sánchez-Osorio, I. Analysis of Prinobius myardi Mulsant population dynamics in a Mediterranean cork oak stand. Ann. Soc. Entom. Franc. 2011, 47, 260-268. [CrossRef]

25. Tiberi, R.; Branco, M.; Bracalini, M.; Croci, F.; Panzavolta, T. Cork oak pests: A review of insect damage and management. Ann. For. Sci. 2016, 73, 219-232. [CrossRef]

26. Duque-Lazo, J.; Navarro-Cerrillo, R.M. What to save, the host or the pest? The spatial distribution of xylophage insects within the Mediterranean oak woodlands of Southwestern Spain. For. Ecol. Manag. 2017, 392, 90-104. [CrossRef]

27. Lopez-Pantoja, G.; Domínguez, L.; Sanchez-Osorio, I. Mark-recapture estimates of the survival and recapture rates of Cerambyx welensii Küster (Coleoptera Cerambycidae) in a cork oak dehesa in Huelva (Spain). Open Life Sci. 2008, 3, 431-441. [CrossRef]

28. Lopez-Pantoja, G.; Domínguez, L.; Sanchez-Osorio, I.; Tapias-Martin, R.; Cremades, D.; Paramio, A.; Alesso, P. Population Ecology of Xilophagus Beetles (Coleoptera: Cerambycidae) in Mediterranean Quercus Forest (Southwest of the Iberian Peninsula). Incidence on Oak Trees Health (Quercus ilex L. Ssp. Ballota and Quercus suber L.). In Ecology, Conservation and Management of Mediterranean Climate Ecosystems. International Conference on Mediterranean Climate Ecosystems; Arianoutsou, M., Papanastasis, V.P., Eds.; (Medecos). Num. 10; Millpress: Rhodes, Greece; Rotterdam, The Netherlands, 2004; p. 66.

29. Martín, J.; Cabezas, J.; Buyolo, T.; Patón, D. The relation between Cerambyx damage and Biscogniauxia. For. Ecol. Manag. 2005, 216, 166-174. [CrossRef]

30. WWF. WWF Cambios en el Uso del Suelo en el Entorno de Doñana entre POTAD y 2009. 2009. Available online: http:/ / awsassets wwf.es/downloads/informe_cultivos_ilegales_en_donana_wwf.pdf (accessed on 28 November 2016).

31. Plieninger, T.; Pulido, F.J.; Konold, W. Effects of land-use history on size structure of holm oak stands in Spanish Dehesas, implications for conservation and restoration. Environ. Conserv. 2003, 30, 61-70. [CrossRef]

32. Jolly, G.M. Explicit estimates from capture-recapture data with both death and immigration-Stochastic model. Biometrika 1965, 52, 225-247. [CrossRef] [PubMed]

33. Pollock, K.H.; Nichols, J.D.; Hines, J.E.; Brownie, C. Statistical inference for capture-recapture experiments. Wildl. Monogr. 1990, 107, 3-97.

34. Seber, G.A.F. A review of estimating animal abundance II. Int. Stat. Rev. 1992, 60, 129-166. [CrossRef]

35. Schwarz, C.J.; Arnason, A.N. A general methodology for the analysis of open-model capture recapture experiments. Biometrics 1996, 52, 860-873. [CrossRef]

36. White, G.C.; Burnham, K.P. Program MARK: Survival estimation from populations of marked animals. Bird Study 1999, 46 (Suppl. S1), 120-138. [CrossRef]

37. Burnham, K.P.; Anderson, D.R.; White, G.C.; Brownie, C.; Pollock, K.H. Design and analysis of fish survival experiments based on capture-release. Am. Fish. Soc. Monog. 1987, 5, 1-437.

38. Choquet, R.; Reboulet, A.M.; Lebreton, J.D.; Gimenez, O.; Pradel, R. U-CARE 2.2 User's Manual; CEFE. UMR 5175, CNRS: Montpellier, France, 2005.

39. Starkey, D.A.; Oliveria, F.; Mangini, A.; Mielke, M. Oak decline and red oak borer in the interior highlands of Arkansas and Missouri: Natural phenomena, severe occurrences. In Upland oak Ecology Symposium: History, Current Conditions, and Sustainability; Spetich, M.A., Ed.; Gen. Tech. Rep; SRS-73; U.S. Department of Agriculture, Forest Service, Southern Research Station: Asheville, NC, USA, 2004; pp. 217-222.

40. Fierke, M.K.; Kinney, D.L.; Salisbury, V.B.; Crook, D.J.; Stephen, F.M. A rapid estimation procedure for within-tree populations of red oak borer (Coleoptera, Cerambycidae). For. Ecol. Manag. 2005, 215, 163-168. [CrossRef] 
41. Fan, Z.; Kabrick, J.M.; Spetich, M.A.; Shifley, S.R.; Jensen, R.G. Oak mortality associated with crown dieback and oak borer attack in the Ozark. For. Ecol. Manag. 2008, 255, 2297-2305. [CrossRef]

42. Naveiro, F.; Pulido, F.J.; Del Pozo, J.D.; Morcuende, A.; González, M.A.; Muñoz, J. Situación fitosanitaria del arbolado de las dehesas en Extremadura, Influencia de las labores silvícolas. Bol. San. Veg. Plagas 1999, 25, 425-433.

43. Torres-Vila, L.M.; Sánchez-González, A.; Ponce-Escudero, F.; Martín-Vertedor, D.; Ferrero-García, J.J. Assessing mass trapping efficiency and population density of Cerambyx welensii Kuster by mark-recapture in dehesa open woodlands. Eur. J. For. Res. 2012, 131, 1103-1116. [CrossRef]

44. Riggins, J.J.; Galligan, L.D.; Stephen, F.M. Rise and fall of Red Oak Borer (Coleoptera, Cerambycidae) in the Ozark Mountains of Arkansas, USA. Fla. Entomol. 2009, 92, 426-433. [CrossRef]

45. Acácio, V. The Dynamics of Cork Oak Systems in Portugal: The Role of Ecological and Land Use Factors. Ph.D. Thesis, Wageningen University, Wageningen, The Netherlands, 2009.

46. Acácio, V.; Holmgren, M. Pathways for resilience in Mediterranean cork oak land use systems. Ann. For. Sci. 2014, 71, 5-13. [CrossRef]

47. Hidalgo, P.; Marín, J.; Quijada, J.; Moreira, J.A. Spatial distribution model of cork oak (Quercus suber) in southwestern Spain, a suitable tool for reforestation. For. Ecol. Manag. 2008, 255, 25-34. [CrossRef]

48. Benito, M.; Sánchez de Dios, R.; Sainz-Ollero, H. Effects of climate change on the distribution of Iberian tree species. Appl. Veg. Sci. 2008, 11, 169-178. [CrossRef]

49. Correia, B.; Rodriguez, J.L.; Valledor, L.; Almeida, T.; Santos, C.; Cañal, M.J.; Pinto, G. Analysis of the expression of putative heat-stress related genes in relation to thermotolerance of cork oak. J. Plant Physiol. 2014, 171, 399-406. [CrossRef]

50. Piayda, A.; Dubbert, M.; Rebmann, C.; Kolle, O.; Costa e Silva, F.; Correia, A. Drought impact on carbon and water cycling in a Mediterranean Quercus suber L. woodland during the extreme drought event in 2012. Biogeosciences 2014, 11, 10365-10417. [CrossRef]

51. Pausas, J.G.; Fernández-Muñoz, S. Fire regime changes in the Western Mediterranean Basin: From fuel-limited to drought-driven fire regime. Clim. Chang. 2012, 110, 215-226. [CrossRef]

52. Torres-Vila, L.M.; Sánchez-González, A.; Merino-Martínez, J.; Ponce-Escudero, F.; Conejo-Rodríguez, Y.; Martín-Vertedor, D.; Ferrero-García, J.J. Mark-recapture of Cerambyx welensii in dehesa woodlands: Dispersal behaviour, population density, and mass trapping efficiency with low trap densities. Entomol. Exp. Appl. 2013, 149, 273-281. [CrossRef]

53. Sánchez-Osorio, I.; López, G.; Paramio, A.; Lencina, J.L.; Domínguez, L. Field attraction of Cerambyx welensii to fermentation odors and host monoterpenos. J. Pest Sci. 2016, 89, 59-68. [CrossRef]

54. Donley, D.E. Control of the Red Oak Borer by Removal of Infested Trees. J. For. 1981, 79, 731-733. [CrossRef] 